BECHLER, Reinaldo Guilherme.

Hansen versus Neisser: controvérsias científicas na 'descoberta' do bacilo da lepra. História, Ciências, Saúde-

Manguinhos, Rio de Janeiro, v.19, n.3, jul.-set. 2012, p.815-841.

\title{
Resumo
}

\section{Hansen versus Neisser: controvérsias científicas na 'descoberta' do bacilo da lepra}

Hansen versus Neisser: scientific controversies over the 'discovery' of the bacillus of leprosy
Analisa o conturbado processo científico que levou à 'descoberta' do bacilo causador da lepra, na Europa, na segunda metade do século XIX, e que envolveu alguns dos principais nomes da ciência médica do período, como Robert Koch, Rudolf Virchow e Armauer Hansen. Compreendida como paradigma científico, tal 'descoberta' será aqui reexaminada historicamente através de fontes primárias ainda pouco trabalhadas na América Latina.

Objetiva-se oferecer novos instrumentos de análise e de reflexão para a historiografia das ciências, posto que serão identificados aspectos culturais, sociais e mesmo nacionalistas na construção desse paradigma.

Palavras-chave: história da lepra; história da bacteriologia; Armauer Hansen (1841-1912); controvérsia científica.

Abstract

This paper analyzes the turbulent scientific process that led to the 'discovery' of the bacillus that causes leprosy, which occurred in Europe in the second half of the nineteenth century and which involved some of the leading names in medical science of the period, such as Robert Koch, Rudolf Virchow and Armauer Hansen. Understood as a scientific paradigm, this 'discovery' is reexamined here based on primary sources as yet only partially researched in Latin America. The scope of this paper is to provide new instruments for analysis and reflection for the historiography of the sciences, as the cultural, social and even nationalist aspects are identified in the construction of this paradigm.

Keywords: history of leprosy; history of bacteriology; Armauer Hansen (18411912); scientific controversy. 
$\mathrm{F}$ ruto de reflexões e questionamentos instigados por minha pesquisa de doutoramento recentemente defendida na Universidade de Würzburg, na Alemanha (Bechler, 2010), este trabalho pretende cumprir dois objetivos básicos: contextualizar, a partir da segunda metade do século XIX, o processo de produção dos primeiros conhecimentos científicos acerca da lepra enquanto enfermidade bacteriológica, que culminaria na 'descoberta' de seu agente etiológico na década de 1880; e empreender uma breve revisão historiográfica desse processo, salientando a maneira pela qual os discursos sobre tal feito foram influenciados por fatores de natureza política e cultural.

Esse processo apresenta-se, até os dias atuais, bastante vinculado à figura do médico norueguês Armauer Hansen (1841-1912), reconhecido como autor incontestável da 'descoberta'. Pode-se afirmar antecipadamente que Hansen não estava sozinho. Outros personagens também lutaram por essa glória científica. Por que somente Hansen recebeu todos os louros da 'descoberta'? O que teria feito para se tornar o principal nome científico relacionado à lepra em todos os tempos? Quais eram e que papel desempenharam figuras não menos importantes - mas colocadas em plano secundário - como Albert Neisser (1855-1916) e Robert Koch (1843-1910), e por que até hoje não são reconhecidas? O que representou esse processo no efervescente contexto científico do século XIX?

Ele será aqui examinado não como "revelação dos segredos da natureza", e sim como construção sociológica, que envolveu questões científicas e pessoais, disputas, egolatrias e ciúmes (Brannigan, 1981). A intenção deste trabalho é, em última instância, aproximar o campo da observação histórica dos agentes humanos envolvidos no processo de maneira a tornar suas motivações e atitudes compreensíveis.

Ao analisar a produção de discursos científicos acerca do diagnóstico da sífilis, Ludwik Fleck (1979) mostrou que um fato científico não é simplesmente descoberto por um indivíduo, uma vez que constitui um fenômeno social coletivamente construído e bastante influenciado por estruturas e parâmetros de uma época (Moraes, 2001). Charles Rosenberg (1992) também abriu novas e profícuas perspectivas historiográficas, nas últimas décadas, ao conceber a doença como entidade imprecisa e inacabada, a um só tempo fato biológico e entidade produtora de discursos. Para esse autor, as doenças não podem ser analisadas em separado de suas representações sociais. Ao amalgamá-las aos fenômenos sociais e culturais, Rosenberg atribuiu novos significados aos eventos biológicos, abrindo outras perspectivas à interpretação histórica.

De maneira geral, a discussão teórica sobre o processo das 'descobertas' científicas tem sido um tema bastante profícuo na historiografia e sociologia da ciência contemporâneas. Para Bruno Latour (1998), por exemplo, a certificação do conhecimento científico depende de uma série de procedimentos e estratégias por parte dos cientistas para convencer outros indivíduos e grupos a aceitar - e utilizar - as afirmações e objetos por eles produzidos. Para analisar a ciência em ação, ou seja, os processos efetivos pelos quais se estabilizam os fatos científicos, é preciso, diz Latour (1998, p.57), "seguir os cientistas sociedade afora" e examinar os recursos de que lançam mão para "mobilizar o mundo" e produzir concretamente, em circunstâncias específicas, o consenso necessário à produção desses paradigmas ou, seguindo sua conceituação, dessas "caixas-pretas". No estudo etnográfico de laboratório que desenvolveu com Steve Woolgar, Latour analisou pormenorizadamente os mecanismos e estratégias 
persuasivos por meio dos quais os enunciados científicos são formulados e negociados nos espaços particulares do mundo da ciência, como a literatura científica e os instrumentos próprios aos laboratórios (Latour, Woolgar, 1997). Essa é, em última análise, uma dimensão essencial do itinerário em direção à estabilização dos fatos da ciência.

Augustine Brannigan (1981) discute igualmente, com louvável fôlego, os meandros sociais que influenciam e geram 'descobertas' na ciência. Desvelando o conturbado contexto social, político e científico vivido na Europa do século XVII, a autora afirma que tal processo acabou por legar à ciência a responsabilidade de desvendar os mistérios e enigmas de uma natureza vista como realidade regida por leis e estruturas não acessíveis ao público comum. Com efeito, as descobertas científicas acabaram ganhando o status de "essência da ciência" (p.16), tanto na imaginação dos cientistas como do público em geral, em um processo que ainda se faria presente na segunda metade do século XIX, período caro a este trabalho.

Alinhando-se metodologicamente à argumentação dos autores citados, pretendo analisar a 'descoberta' do agente etiológico da lepra não como "revelação dos segredos da natureza", e sim como construção sociológica e subjetiva, envolvendo questões científicas e humanas.

\section{O retorno da lepra à Europa: estigma x ciência}

Considerada extinta do território europeu desde o final do século XVII, a lepra voltou a ser registrada em proporções endêmicas no início do século XIX (Hansen, Lie, 1909). A justificável preocupação com a salubridade e o bem-estar da população tinha o respaldo de médicos e higienistas cada vez mais especializados e com conhecimentos cada vez mais sofisticados sobre a natureza em todas as suas manifestações. Em termos teóricos, esse fenômeno pode ser analisado à luz de um conceito sociológico bastante difundido nas últimas décadas em história da medicina: o de 'medicalização'. Tal conceito designa aqui a expansão do discurso e da prática médica sobre o campo social, especialmente a partir do século XVIII, o que resulta na tradução dos fenômenos sociais em conceitos de um determinado campo de saber. Em outras palavras, trata-se do esforço de médicos em classificar um número cada vez maior de aspectos do comportamento humano, antes encarados simplesmente como normais ou anormais pelo público em geral, agora como sinais de saúde ou doença.

No terreno sociológico, tal conceito tem sido motivo de importantes controvérsias nas últimas décadas. Para Michael Stolberg (1998), desde seu surgimento nos anos 1960, o conceito de medicalização foi objeto de apropriações bastante distintas, motivo pelo qual esse autor considera até certo ponto um equívoco a indicação de Michel Foucault (2006) como autor da ideia, especialmente em O nascimento da clínica, embora, de fato, ela tenha ganhado maior circulação acadêmica a partir de então. Jacques Léonard (1978, p.23) também utilizou 'medicalização' com o sentido de "aumento da atuação oficial em questões relacionadas à saúde no cotidiano de uma população". No caso abordado no presente artigo, o conceito designa um motor ideológico que transformou a lepra em um problema social, científico e político dos mais graves na virada dos séculos XIX para o XX. 
Enquanto problema clínico, a lepra "foi uma das primeiras doenças infecciosas a ser reestruturada à luz da microbiologia" (Benchimol, Sá, 2005, p.28). Reverencia-se aqui o trabalho publicado em 1848 por Daniel Cornélius Danielsen (1815-1894) e Carl Boeck (1808-1875), que descortinou os horizontes do estudo da lepra, sendo reconhecido até hoje como o primeiro trabalho científico sobre essa enfermidade milenar. No que tange à sua etiologia, esses médicos noruegueses a reconheceram, essencialmente, como doença hereditária; entretanto, além de não desconsiderarem possíveis influências da insalubridade e de outros fatores como responsáveis por sua incidência, deixavam claro o caráter incipiente e vanguardista do estudo que empreenderam, conclamando os médicos de seu tempo ao estudo aprofundado da enfermidade. A partir da década de 1850, observa-se um profícuo processo acadêmico-científico voltado para o estudo da lepra em diversos países europeus.

Esse período da história humana foi marcado pela velocidade com que se desenvolveram os conhecimentos em diversas ciências, especialmente as da saúde, gerando, além disso, acalorados processos acadêmicos e políticos que merecem atenção histórica. Estudos científicos sobre células e tecidos, por exemplo, que se desenvolviam de maneira considerável já desde o final do século XVIII, receberam grande impulso em meados do século XIX, com as novas técnicas de coloração desenvolvidas no período, que tornavam possível a visualização em microscópios cada vez mais potentes de uma gama até então desconhecida de microrganismos. A especialidade que viria a se chamar dermatologia passou a compreender a pele humana como algo muito mais complexo do que o simples envoltório do corpo, também como local de lesões capazes de explicar diversos processos patológicos.

Descrito por Andrew Cunningham e Perry Williams (1992, p.32) como "um dos principais instrumentos científicos do século XIX", o microscópio alavancou o interesse científico por várias doenças, que passaram a ser objeto de estudos de uma categoria recém-formada no campo médico, convencionalmente chamada de 'bacteriologistas'. Essa "revolução microbiana" (p.14) modificou comportamentos médicos, ampliou horizontes investigativos e criou uma atmosfera de competição acadêmica por prestígio e poder entre esses profissionais.

No espectro de doenças de interesse para esses bacteriologistas, a lepra transformou-se em um desafio, uma vez que sua cura pela prática clínica era um objetivo sabidamente distante (Yoshie, 1973; Monteiro, 1995; Obregón-Torres, 2000).

A análise de Eric Hobsbawn (1988) sobre A era dos impérios oferece subsídios para que interpretemos esse interesse científico pelos estudos leprológicos como momento imperial ou colonial da lepra. Afinal, no final do século XIX e início do XX, as principais nações europeias preocupavam-se sobremaneira com a expansão comercial e econômica, e em quase todas as regiões onde o imperialismo foi observado, a lepra constituía um sério problema endêmico (Edmond, 2006).

O problema apresentava-se então do seguinte modo: a lepra, doença tão estigmatizada e temida, era novamente encontrada em números consideráveis e alarmantes, até mesmo na Europa. Respostas científicas tornavam-se urgentes. Estava deflagrada a competição entre cientistas para a obtenção dessas respostas. 


\section{Os primeiros passos científicos na Noruega}

A Noruega foi o primeiro país a encarar a lepra como problema de Estado, já na primeira metade do século XIX. A independência do país do reino da Suécia, sacramentada em 1814, aguçou um ambiente nacionalista que fez do desenvolvimento da ciência no país uma prioridade inconteste (Irgens, 1973; Gussow, 1989; Obregón-Torres, 2000). Apontada como principal mazela nacional, a lepra passou a representar um entrave à nova nação. Combatê-la de modo exemplar tornava-se um imperativo político e uma necessidade social (Irgens, 1973; Almas, Brynjulv, 2004).

Para alcançar esse objetivo, o governo escandinavo dispôs-se a formar e a financiar a primeira classe de médicos especialistas na enfermidade, a partir da década de 1830, com a expectativa de que produzissem os primeiros conhecimentos efetivamente técnicos sobre o problema (Vogelsang, 1957; Irgens, 1973). O responsável pelas primeiras iniciativas contra a lepra na Noruega foi o médico, intelectual e político Jens Johan Hjort (1798-1873). "Hjort foi realmente o pai das medidas implantadas no país contra a lepra nos anos seguintes"1 comentaria Armauer Hansen (Hansen, Lie, 1909, p.327).

Gozando de autonomia concedida pelo governo norueguês, Hjort nomeou em 1839 o médico recém-formado Daniel Danielsen, à época, com 24 anos, para assumir em Bergen o posto de médico-pesquisador no St. Jörgens Hospital, antigo leprosário medieval, transformado na década de 1830 em centro de estudos da lepra. Meses depois, Danielsen ganhou a companhia do professor de dermatologia da Escola Médica de Christiania ${ }^{2}$, Carl W. Boeck, que seria seu assistente por toda a vida (Yoshie, 1973). Acordou-se que Danielsen seria o responsável por desenvolver os primeiros estudos clínicos da lepra em Bergen, enquanto Boeck teria a incumbência de viajar pelos principais centros científicos europeus no intuito de atualizar o país em relação a novos procedimentos técnicos para lidar com a doença.

Como principal resultado desses primeiros e árduos anos de pesquisa, Danielsen e Boeck (1848) publicaram, o já mencionado livro Traité de la spédalsked ou eléphantiasis de grecs. No mesmo ano, os autores receberam o Prix Monthyon, prêmio de dois mil francos da Academia Francesa (Hansen, Lie, 1909), o que nos dá uma noção da relevância da obra no contexto científico da época. Provavelmente em decorrência do sucesso de sua pesquisa, Danielsen assumiu, em 1849, o papel de autoridade máxima do governo norueguês no tocante à lepra - papel anteriormente exercido por Hjort - e passou a dar as cartas no combate à doença.

Nesse livro, a lepra foi definida como entidade nosológica e diferenciada da sífilis, do escorbuto, das psoríases, da tuberculose e da sarna. No que tange à sua etiologia, Danielsen e Boeck deixaram claro que tinham argumentos suficientes para acreditar na tese da hereditariedade. Para tanto, baseavam-se somente em observações empíricas, que apontavam para uma incidência incomum da enfermidade em membros da mesma família (Danielsen, Boeck, 1848).

Necessária se faz a constatação histórica de que tal teoria anticontagionista também abarcou outras enfermidades no período, como a peste, o cólera e a febre amarela, (Ackerknecht, 1948), mas, em linhas gerais, teve curta duração e, já no começo da década de 1870 , começou a perder força. 
No que tange à caracterização etiológica da lepra nesses primeiros momentos da ação norueguesa, as dificuldades seriam imediatamente refletidas nas medidas práticas adotadas no país que, conforme apontou Hansen posteriormente, tinham como objetivos: "Em parte curar os leprosos e em parte oferecer boa alimentação aos leprosos pobres e prevenir o quanto possível o aumento da população" (Hansen, Lie, 1909, p.333). ${ }^{3}$

Autores como Yoshio Yoshie (1973, p.361) apontam as duas principais contribuições do trabalho de Danielsen e Boeck (1848, p.132): em primeiro lugar, a diferenciação fundamental entre dois tipos de lepra, classificados como "nodular" e "anestésico"; em segundo lugar, a observação do que chamaram de massas granulares ou elementos marrons em preparados histopatológicos retirados de nódulos leprosos.

Como autoridade máxima do governo norueguês no assunto, Danielsen gozava de respaldo político para o desenvolvimento de suas teorias. Seu trabalho iniciou uma nova era no combate à lepra, pela primeira vez compreendida como um problema de saúde pública por uma nação (Sternersen, Libaek, 2003; Bechler, 2010).

Uma vez que os estudos sobre a etiologia da doença mostravam-se pouco produtivos, apesar de seus esforços, Danielsen tomou a iniciativa de buscar opiniões de cientistas envolvidos com estudos de outras enfermidades. Atendendo, assim, a uma solicitação de Danielsen, feita no início de 1859, o governo norueguês convidou o médico alemão Rudolf Virchow (1821-1902) para uma visita a Bergen (Yoshie, 1973; Vasold, 1989). Virchow gozava, à época, de relativo prestígio acadêmico internacional, seja por seus estudos sobre patologia celular, seja por ser o responsável por uma das principais revistas científicas europeias no período, a Virchows Archiv. Os objetivos do convite estavam claros para Danielsen: apresentar a uma das principais autoridades científicas de seu tempo as pesquisas desenvolvidas no país sobre a lepra e tirar proveito dos conhecimentos de Virchow sobre patologia celular, de modo a aplicá-los em suas pesquisas. De maneira mais específica, o norueguês almejava apresentar a Virchow suas conjecturas acerca dos "elementos marrons" e suas possíveis implicações para a etiologia da lepra.

Em carta a seus pais, Virchow descreveria da seguinte maneira a viagem à Noruega:

Viajo amanhã cedo para Lübeck, para de lá seguir rumo a Bergen. O distrito mais afetado pela doença e sobre o qual o governo norueguês almeja saber minha opinião sobre suas pesquisas no campo da lepra é Bergen-Stift. Lá devo permanecer a maior parte do tempo. Devo permanecer de cinco a seis semanas por lá e espero poder contribuir de alguma forma (Rabl, 1906, p.218). ${ }^{4}$

Segundo a interpretação de Yoshie (1973, p.361), Virchow não se mostrou muito interessado nas conjecturas de Danielsen, interpretando os "elementos marrons" como "meros fragmentos de gordura degenerada". ${ }^{5} \mathrm{O}$ que realmente chamou a sua atenção foi a quantidade de casos registrados da doença. Afinal, como ressaltado anteriormente, até aquele momento, a lepra era considerada uma enfermidade praticamente extinta no continente europeu. Em uma palavra: a questão epidemiológica chamou mais a atenção de Virchow do que a científica. Combater o risco de uma epidemia era, de seu ponto de vista, mais importante naquele momento do que estudar cientificamente o agente etiológico.

Inicialmente prevista para cinco ou seis semanas, a visita de Virchow durou apenas 13 dias. Em termos práticos, sua estada na Noruega serviu, por um lado, para aproximá-lo 
acadêmica e pessoalmente das autoridades norueguesas; por outro, para inflamar o clamor científico sobre a lepra na Europa. Ao retornar a seu país, Virchow também começou a estudar detidamente a lepra. Menos de um ano depois, publicaria na revista que levava seu nome a primeira das quatro partes da obra que é reconhecida até hoje como um clássico da história da lepra na Alemanha: Zur Geschichte des Aussatzes, besonders in Deutschland (Sobre a história da lepra, especialmente na Alemanha), que contribuiu indubitavelmente para despertar novamente o interesse da ciência alemã e europeia pela doença (Virchow, 1860, 1861, 1862, 1864). Se os estudos bacteriológicos de Danielsen sobre a lepra não despertaram, a princípio, o interesse de Virchow, a situação modificou-se sobremaneira nos anos subsequentes. Um pouco mais tarde (1863), o alemão descreveu a histopatologia da lepra lepromatosa, identificando o granuloma lepromatoso. Essa forma da doença passou a ser chamada de virchowiana, em sua homenagem, nomenclatura que permanece válida ainda hoje (Cabral, 2006).

A Danielsen, por sua vez, restou a constatação de que seus estudos eram ainda incipientes, e que seria árduo o caminho até a obtenção de respostas sobre a etiologia da lepra. Apesar de todo o seu esforço nesses anos de estudo e dedicação, os resultados de suas pesquisas ainda se mostravam inconclusivos. Essa era a situação ao final da década de 1860, quando entrou em cena Armauer Hansen.

\section{O papel de Armauer Hansen}

Em outubro de 1868, Danielsen admitiu um estudante de medicina da Universidade de Christiania como seu assistente no hospital de Lungegaard: Gerhard Henrik Armauer Hansen (Hansen, Lie, 1909; Larsen, 1973; Bechler, 2010). Iniciava-se assim uma relação pessoal e científica bastante próxima.

Rapidamente, Hansen tornou-se presença assídua na residência dos Danielsen e acabou se casando com Stephanie Marie, única filha do chefe. O casamento, entretanto, teria um fim trágico, com o falecimento de Stephanie, nove meses mais tarde, por complicações de uma tuberculose fulminante. ${ }^{6} \mathrm{O}$ ocorrido aumentou o elo de amizade entre os dois médicos, além de tornar Hansen um obcecado pelo trabalho científico, capaz de lhe fornecer respostas práticas para seu sofrimento pessoal. Considerando-se "uma pessoa muito religiosa" (Hansen, 1976, p.78) ${ }^{7}$ até a tragédia, ele descreve esse período de sua vida com muita tristeza em sua autobiografia.

Apresentava-se ao trabalho em colaboração com Danielsen com o respaldo de uma excelente formação universitária, ainda em curso (Larsen, 1973), e recebeu de bom-grado a incumbência de atualizar os conhecimentos científicos noruegueses sobre a doença. Possivelmente motivado pelos referidos acontecimentos particulares, Hansen pediu a seu chefe, como tarefa inicial, para viajar pelo país para coordenar o cadastramento de doentes, o que já vinha sendo feito desde o final da década de 1850 (Larsen, 1973; Bechler, 2010). Hansen pôde então conhecer a doença em sua forma mais crua, visitando lares de camponeses pelo interior da Noruega.

A precária situação sanitária e de vida de seus conterrâneos - que, diga-se de passagem, já tinha impressionado Boeck e Danielsen - assustou profundamente o jovem médico 
escandinavo: "Sofri terrivelmente. Nunca tinha visto tanta miséria concentrada em um só lugar" (Hansen, 1976, p.70). ${ }^{8}$ A promiscuidade, a falta de cuidados mínimos com higiene e salubridade constituiriam, para ele, uma porta aberta para várias enfermidades. Hansen ficou também intrigado com a maneira pela qual as pessoas reagiam a essa condição de "doentes em potencial". Pôde assim compreender na prática mais uma das implicações da - ainda imprecisa - teoria da hereditariedade da lepra, em voga no período. Por ser uma enfermidade bastante vinculada a fatores religiosos, tal concepção reforçava a ideia de que ela provinha de um castigo divino, contra o qual não cabia contestação ou queixa.

A leitura da autobiografia de Hansen me leva a corroborar a interpretação de outros autores. Sendo também religioso, como criticar a postura dos camponeses em face da vontade de Deus? Seu nascente interesse por uma explicação humana e científica para o problema se chocaria cada vez mais com suas convicções íntimas (Larsen, 1973; Irgens, 1973).

A partir de então, Hansen começou a questionar a validade da teoria da hereditariedade da lepra. A observação do modo como viviam as pessoas robusteceu a convicção de que a condição sanitária e os hábitos promíscuos da população poderiam causar doenças, a lepra entre elas.

Logo após finalizar esse período de viagens, Hansen publicaria seu trabalho de conclusão de curso em 1869. Devido à considerável ressonância acadêmica da obra, o pesquisador ganhou uma bolsa de estudos do governo norueguês para estudar a doença no exterior, o que denota uma preocupação das autoridades norueguesas em formar um sucessor para o já idoso Daniel Danielsen.

Em agosto de 1870, Hansen desembarcou em Bonn, na Alemanha, para trabalhar como pesquisador visitante no Max Schultze Institut, na ocasião um dos principais centros de estudos em ciências naturais do mundo. Sua permanência na cidade alemã coincidiu com o início da Guerra Franco-prussiana. A efervescência social e os riscos trazidos por aquele conflito militar levaram-no a mudar de cidade, pois ali já não conseguia a devida concentração para o trabalho. "Até mesmo para mim, um estrangeiro, foi difícil sentar-se calmamente à frente de um microscópio sob tais circunstâncias" (Hansen, 1976, p.82). ${ }^{9}$

Assim, no início de 1871, mudou-se para Viena e aí conheceu uma série de personalidades artísticas e científicas, absorvendo inovadoras concepções filosóficas e um ritmo de vida boêmio, narrados de maneira interessante em sua autobiografia. Através da análise histórica das obras que leu neste período, podemos compreender melhor o desenvolvimento de suas concepções científicas - e mesmo íntimas. Até sua chegada à capital austríaca, o norueguês concentrava-se quase que exclusivamente em livros técnicos sobre medicina em geral. Em Viena, Hansen teria contato com um livro revolucionário, de Charles Darwin, que transformaria para sempre a sua existência:

Também em Viena deu-se um dos acontecimentos mais importantes de minha vida. Tudo começou de uma forma bastante comum, caminhando por uma livraria, mas quando me deparei com uma cópia de Natural evolution, o destino se transformaria. O próprio título contestava todas as minhas convicções sobre a criação. Fui para casa fascinado pela minha compra, lendo o livro em dois dias, no esquecimento completo do meu laboratório. Nunca havia lido nada parecido. O mundo inteiro se mostrou com uma luz inteiramente diferente daquela que eu conhecia. Tudo o que me haviam ensinado desde a infância, caiu como algo irreal (Hansen, 1976, p.83). ${ }^{10}$ 
O processo de dessacralização do mundo e da natureza instigado pelo pensamento de Darwin, com reflexos incontestes na sociedade e na ciência do século XIX, também se fez observar no pensamento de Armauer Hansen, e em suas futuras ações direcionadas à lepra. Repentinamente, Hansen encontrava respostas para a sua inquietação, nascida da aceitação de seus conterrâneos à "vontade de Deus" e, consequentemente, à condição de doente, observada nas viagens pelo interior da Noruega. Ao conviver em ambientes insalubres, expondo-se, assim, à incursão dos mais diversos microrganismos - então cada vez mais bem compreendidos como agentes de processos fermentativos e quiçá patológicos - os camponeses noruegueses visitados por Hansen estavam expostos a elevados riscos de contaminação. Munido de Darwin, Hansen transformava-se em contundente crítico às explicações hereditárias da lepra: "Minhas inquietações científicas já me haviam preparado espiritualmente para absorver o choque mental daqueles dois dias" (Hansen, 1976, p.83). ${ }^{11}$

Além disso, após a leitura do trabalho do naturalista britânico, Hansen declarou-se agnóstico. Para ele, tornou-se inconcebível o consórcio "fazer ciência e ser religioso". Fazer ciência, segundo sua concepção, significava revelar mecanismos humanos e biológicos subjacentes a eventos que não poderiam mais ser atribuídos somente a Deus:

Deixe-me primeiro discutir ainda outro ponto importante aqui. É o seguinte: pessoas, em sua ânsia por respostas sobre o enigma da vida - ainda tão pouco conhecido imaginam ter chegado a uma solução via a criação de um Deus do qual tudo brota e que é realmente Todo-Poderoso. Eles ignoram que esse Deus também exige uma origem. Fugir a essa demanda, apenas fazendo-o onipotente e eterno é simplesmente uma admissão de ignorância (Hansen, 1976, p.86). ${ }^{12}$

Hansen ainda permaneceria algum tempo na capital austríaca, retornando a Bergen no final de 1871 para reassumir o cargo de assistente de Danielsen. Na bagagem, levava a responsabilidade de fazer germinarem aquelas ideias revolucionárias em sua sociedade. Contudo, via-se numa incômoda situação. Seria necessário assumir uma postura científica antagônica à de seu mentor e sogro, o principal partidário da tese da hereditariedade da lepra.

Em 1874, Hansen publicou um trabalho na principal revista científica norueguesa no qual fazia a análise microscópica de uma célula que continha material leproso, nele observando microrganismos que julgou parecidos com 'bastões', indício de que poderiam ser o agente etiológico da lepra. Sua argumentação deixava claro, contudo, que seria longo o caminho até conhecimentos mais específicos sobre o assunto:

\footnotetext{
Como os resultados dos exames ainda são incertos, e eu pretendo continuar a pesquisa, eu não quero mencionar em artigos os detalhes de minhas observações. Ainda faltam muitos detalhes para a demonstração correta de uma especificidade da lepra, mas eu também achei que deveria oferecer neste artigo um parecer sobre minhas investigações, o que eu pretendi fazer (Hansen, 1874, p.307). ${ }^{13}$
}

Hansen e Lie (1909, p.333), seu assistente, 35 anos depois, descreveriam esse importante momento da história da lepra em comunicação por ambos apresentada na Conferência de Bergen, em 1909:

Ele [Hansen] estudou primeiro os fenômenos clínicos e a anatomia patológica da doença. As chamadas células leprosas virchowianas que, muito tempo antes, Danielsen já havia 
chamado em seu trabalho de forma anestésica da lepra, foram vistas por ele como algo característico da lepra. ... Hansen as chamou de "corpos marrons" e as encontrou por todas as produções leprosas, reconhecendo também que elas não poderiam ser vistas como células degeneradas, como interpretou inicialmente Virchow, concluindo que elas seriam formas características de lepra. ... Por meio dessas observações e do fato de que o fígado, o baço e os testículos dos leprosos sempre estavam infetados por esses nódulos, e por meio das observações clínicas sobre o desenvolvimento da enfermidade, chegou à convicção de que a lepra seria uma doença específica e de que ela também precisaria ter uma causa específica, e de que, por conta disso, o ensinamento de Danielsen e Boeck sobre sua etiologia dificilmente estaria correto. ${ }^{14}$

O que Hansen chamou de "corpos marrons" já havia sido descrito por Danielsen e Boeck, em 1848, com o mesmo nome (Wade, 1964). De qualquer forma, no artigo de 1874, Hansen dava um importante passo no desenvolvimento técnico dos conhecimentos sobre a etiologia da lepra, ainda que lhe faltassem métodos e regras acadêmicas suficientes para validar tais considerações naquele momento.

Por seu caráter pouco conclusivo, o artigo de Hansen recebeu várias críticas dos partidários da tese da hereditariedade, inclusive de Danielsen (Obregón-Torres, 2000; Yoshie, 1973; Bechelli, 1973; Irgens, 1973). Essa resposta negativa representou um golpe para Hansen, que já se posicionava de maneira mais explícita contra Danielsen, afastando-se gradativamente de sua influência pessoal e científica.

\section{A 'descoberta' do Mycobacterium leprae}

A querela envolvendo mestre e discípulo no tocante ao desenvolvimento de conhecimentos científicos sobre a lepra nas últimas décadas do século XIX ainda reservava importantes capítulos. Hansen pregava um novo paradigma para a enfermidade, qual seja, o de sua contagiosidade. Já Danielsen insistia na tese da hereditariedade, chegando a ponto de se autoinocular várias vezes com material leproso no intuito de provar que a doença não podia ser transmitida externamente (Irgens, 1973).

Hansen também não ficaria atrás: inoculou material leproso nos olhos de uma paciente sem o seu consentimento para provar seu ponto de vista. Como nos conta Knut Blom (1973), tal atitude custou-lhe caro. A paciente entrou na justiça contra o médico, gerando uma interessante discussão jurídico-científica no país. Por decisão do parlamento norueguês, Hansen chegou a perder por alguns dias o direito de exercer seu cargo público, que lhe foi restituído por uma segunda instância judiciária. Em sua defesa, afirmou estar fazendo ciência e não haver regras estabelecidas para tal prática no país, o que tornava sua ação um ato legítimo (Wade, 1964).

Os esforços científicos a respeito da etiologia da lepra continuaram, contudo, sem conduzir a resultados conclusivos. Em 1875, Hansen publicou em um periódico britânico um segundo artigo com mais detalhes sobre suas pesquisas e no qual se defendia das críticas à sua publicação anterior (Hansen, 1875). Cabe ressaltar que o novo artigo versava sobre a contagiosidade da lepra e sua argumentação consistia quase que integralmente em recursos retóricos. Apenas na última página, Hansen (p.489) mencionava a 'descoberta' do bacilo da lepra, de forma imprecisa e - como de praxe em seus artigos - com muita cautela. 
Enquanto a lepra se revelar, assim, uma doença indiretamente específica, através de demonstrações de sua contagiosidade, o melhor será, obviamente, oferecer uma prova direta. Eu gostaria de, brevemente, apresentar algumas considerações que indicam que tais provas são, talvez, exequíveis. Em todos os leprosos são encontrados tubérculos extirpados de um elemento vivo - e eu tenho examinado um bom número deles - como pequenos bastões, muito parecidos com as bactérias, vivas em todas as células. O que é digno de nota, no entanto, é que os grandes elementos marrons são encontrados em todas as proliferações leprosas em estágios avançados. Ostentam uma notável semelhança com bactérias, em certos estados de seu desenvolvimento. ${ }^{15}$

Havia motivos para essa retórica cuidadosa de Hansen na descrição de suas pesquisas. Por um lado, faltava-lhe experiência ou "autoridade científica" (Bourdieu, 1975) para propor soluções tão específicas; além disso, àquela altura, nenhuma bactéria havia sido acatada como causa de qualquer enfermidade humana, o que só viria a acontecer na virada da década de 1870 para a de 1880; por fim, há que considerar a fulgurante figura científica de Daniel Danielsen, ainda chefe de Hansen e um dos principais críticos da teoria contagionista da lepra.

A controvérsia acerca da localização do micróbio da lepra nos tecidos e líquidos humanos também perduraria alguns anos. A visita do jovem médico alemão Albert Neisser ao laboratório de Hansen, em Bergen, no verão de 1879, infundiria novo fôlego à controvérsia. Então com 24 anos, Neisser era, em Breslau, médico assistente de Robert Koch, pesquisador ainda pouco conhecido, não obstante os trabalhos já desenvolvidos no campo da bacteriologia. Koch passara a se interessar pela lepra. Decorridos cinco anos da publicação do primeiro trabalho de Hansen, os avanços técnicos no estudo dos microrganismos especialmente em relação à potência dos microscópios - facilitavam a observação mais detalhada dos 'infinitamente pequenos' e abriam novas perspectivas para a demonstração da transmissibilidade da lepra, defendida por Hansen.

Era patente, nesse período, o desenvolvimento dos estudos em bacteriologia. Ainda que um dos pilares metodológicos dessa ciência somente viesse a surgir em 1884, com os chamados "postulados de Henle-Koch"16, naquele final da década de 1870 transcorriam inúmeras tentativas de provar que microrganismos eram causadores de enfermidades infecciosas com base nas teorias de Jacob Henle (1809-1885), em voga desde o fim da década de $1860 .{ }^{17}$

Assim, durante a visita de Neisser, Hansen apresentou o estado em que se achavam suas pesquisas, tentando convencer o alemão de que o microrganismo por ele descrito "em formato de bastão", presente em material leproso, era a bactéria causadora da doença (Vogelsang, 1963). Os esforços do médico norueguês foram, porém, infrutíferos em virtude da inconsistência de métodos e evidências que embasassem suas afirmações. De qualquer modo, Neisser sentiu-se instigado a investigar mais e melhor o problema, ao mesmo tempo em que recrudescia a disputa científica pela 'descoberta' da bactéria causadora da lepra (Fite, Wade, 1955; Vogelsang, 1963).

Com essa estada em Bergen, Hansen oferecia a Neisser a oportunidade de conhecer o estado da arte do estudo científico da lepra. Além disso, gentilmente cedeu-lhe ainda preparados contendo material leproso para que Neisser continuasse seus estudos. O jovem 
médico alemão passava a ter recursos para tornar-se um competidor em busca de reconhecimento e glória científica. Ao retornar a Breslau, dedicar-se-ia com grande ímpeto a essa empresa, tendo a seu lado, como professor, ninguém menos que Robert Koch, que logo seria reconhecido como um dos pais da bacteriologia moderna.

No nosso último dia de pesquisa em Bergen, estávamos de maneira liberal às voltas com vários preparados, e ficou claro para mim que seria uma questão de tempo até conseguir enquadrá-los nos métodos de Koch. Ao retornar para meu país com alguns preparados, iniciei imediatamente as pesquisas e, para minha surpresa - sinceramente para meu espanto - encontrei bacilos totalmente desconhecidos em todos os 14 fragmentos de pele e nódulos no fígado, baço, testículo e córnea, o que me encorajou a adentrar no terreno obscuro dessa enfermidade (Neisser, 1879, p.201). ${ }^{18}$

O que Neisser designou como "métodos de Koch" seriam provavelmente as técnicas de coloração e fixação desenvolvidas por esse especialista e aplicadas pelo discípulo às amostras trazidas da Noruega. ${ }^{19}$

Menos de dois meses após retornar de Bergen, Neisser publicou um artigo na primeira edição de Breslauer Aerztlichen Zeitschrift, apresentando o que qualificou como "uma revolução na etiologia da lepra" (Neisser, 1879, p.200). ${ }^{20}$ Neisser (1879, p.201) considerava aquela a primeira descrição academicamente aceitável do microrganismo responsável pela doença.

Os bacilos são pequenos bastões finos, cujo comprimento gira em torno de mais ou menos a metade de um corpo sanguíneo humano tradicional, e cuja largura considero ser de cerca de $1 / 4$ do comprimento. ... Em cortes não coloridos, eu não poderia reconhecer esse pequeno organismo. Eles emergem melhor através da fucsina e da cor violeta genciana. Sua disposição depende do espaço no qual se desenvolvem. ${ }^{21}$

Efetivamente, na referida publicação, Neisser apresentava uma descrição do microrganismo mais detalhada que as de Hansen. Ao fornecer dados sobre as técnicas de coloração empregadas e mesmo sobre aspectos específicos do microrganismo, Neisser tornava definitivamente tumultuado o processo científico do desenvolvimento de conhecimentos sobre a lepra.

Se, do ponto de vista técnico, é possível reconhecer os méritos de Neisser, creio ser difícil afirmar o mesmo do ponto de vista argumentativo. Sendo um investigador ainda inexperiente a tratar de um tema tão incerto como o era o da etiologia da lepra, naquele momento, era de esperar uma argumentação cuidadosa de sua parte quanto aos efeitos práticos de sua contribuição. Neisser $(1879$, p.201) assumia, porém, em seu primeiro artigo, uma postura agressiva em relação aos 'concorrentes', especialmente Danielsen e Hansen.

\footnotetext{
A melhor maneira de exemplificar aos senhores o quão inertes e improdutivas eram as discussões sobre o tema seria afirmando que os dois principais conhecedores da lepra, que ainda hoje vivem... os dois caminhavam em direções científicas totalmente opostas... Danielsen e Hansen, de Bergen. Digo que esses dois pesquisadores se encontram em contradição flagrante. Danielsen considera a doença hereditária e ataca todos que acreditam em sua contagiosidade, enquanto Hansen a compreende como contagiosa e se esforça sempre em glorificar sua capacidade. ${ }^{22}$
}

Hansen, por sua vez, narraria o acontecido em vários momentos de sua vida. Por exemplo, em sua autobiografia: 


\begin{abstract}
Não achei que deveria haver qualquer pressa em publicar minha descoberta, a partir do momento em que sentia que ainda havia muito a ser feito antes de alguém poder alegar que o bacilo era a origem da doença. Neisser não pensou assim. Ele publicou imediatamente, embora honestamente tenha relatado apenas o que eu havia demonstrado a ele. Infelizmente, ele também gravou uma conversa com Danielsen em que meu chefe lhe perguntou, "ironicamente" - segundo Neisser - se eu lhe havia mostrado meu bacilo. Para além desse detalhe, eu já estava inclinado a tomar a decisão de me antecipar, sem entusiasmo, posto que ja reportara a descoberta atual para a norueguesa Magazin of Medical Science (Hansen, 1976, p.98). ${ }^{23}$
\end{abstract}

Ao admitir que já estava inclinado a comunicar a "descoberta" do bacilo da lepra, ainda que "sem entusiasmo", quando Neisser o fez tão apressadamente, Hansen nos oferece um interessante insight para a reflexão histórica e sociológica. Afinal, a afirmação pode nos levar a acreditar que o norueguês tinha o controle de toda a produção de conhecimentos técnicos sobre o agente da lepra, naquele momento, o que seria pouco crível. Além do mais, sabe-se que o processo de arregimentação de fatos científicos é regido por aquilo que Ludwik Fleck chamou de "estilos de pensamento", isto é, enunciados comuns e socialmente construídos, compartilhados por um grupo específico de investigadores envolvidos nas disputas pela formação desses fatos, cujos mecanismos extrapolam a vontade e mesmo a autoridade de qualquer um, individualmente.

A decisão de publicar um artigo até certo ponto ofensivo a Hansen, sem sequer mencionar o fato de que recebera do próprio Hansen o material com o qual chegara a seus resultados, foi recebida de maneira bastante negativa na Noruega. Nas palavras de Hansen (1976, p.99):

Danielsen ficou absolutamente furioso não especialmente com a descrição de Neisser, mas com sua atitude para com o bacilo. Ele me disse severamente que havia sido indolente quanto ao assunto já que, em sua opinião, houve uma tentativa definitiva e deliberada de roubar minha descoberta (Hansen, 1976, p.99). ${ }^{24}$

A participação de Danielsen constitui um capítulo à parte na querela. Embora fosse um dos principais defensores da teoria da hereditariedade da lepra, ele não somente sacramentaria a descrição do microrganismo apresentada por Hansen, como utilizaria suas redes acadêmicas com o intuito de facilitar a circulação de seus artigos. Apesar do duro golpe que significava a reconceituação da lepra como enfermidade causada por uma bactéria, Danielsen se dispôs a apoiar Hansen na quebra do 'paradigma' que viera endossando. Contemporaneamente, historiadores atribuem tal atitude a fatores nacionalistas, ou seja, Danielsen pretendia manter a Noruega na vanguarda dos estudos sobre a lepra (Gussow, 1989; Obregón-Torres, 2000; Fite, Wade, 1955).

Meses depois, no princípio de 1880, Neisser publicaria um segundo artigo, dessa feita no Jahresbericht der Schlesischen Gesellschaft für Vaterländische Kultur. Em um tom bem menos agressivo, reconhecia a participação de Hansen no processo, embora reivindicasse apenas para si o feito de haver provado a existência da bactéria causadora da lepra:

Como consideração final, eu gostaria ainda de repetir que, no mesmo sentido, outros autores, entre eles Hansen, também contribuíram para o processo. De minha parte, apenas me esforcei para provar aos olhos de todos a existência de uma forma de bactéria totalmente específica e sua respectiva disseminação pelo organismo (Neisser, 1880, p.32). ${ }^{25}$ 
A Hansen, por sua vez, foi dada a oportunidade de apresentar à comunidade científica mundial a descrição do agente etiológico da lepra em vários periódicos médicos da época, graças à já mencionada intervenção direta de Danielsen. A primeira dessas publicações se deu, não por acaso, na importante Virchows Archiv, no começo de 1880. Em "Bacillus Leprae", escrito no conturbado final de 1879, Hansen (1880, p.32) oferece-nos mais um testemunho de sua astúcia retórica e de sua exitosa conquista de espaço na história dessa enfermidade milenar:

Eu ainda não havia pensado na possibilidade de publicar minhas pesquisas e pensamentos ... mas como o doutor Neisser, de Breslau, que esteve no último verão em meu laboratório em Bergen para estudar a lepra, acaba de publicar os resultados de suas pesquisas nos preparados que eu mesmo cedi a ele, ... me vi forçado a comunicar minhas observações acerca do mesmo assunto. Aqui pretendo cumprir dois propósitos: primeiro, devo deixar clara minha prioridade no assunto perante ao público científico e, segundo, pretendo apresentar mais detalhes sobre os avanços de minhas investigações da etiologia da lepra em relação a meu primeiro estudo, publicado pela Sociedade de Medicina de Christiania, em $1874 .^{26}$

Hansen, contudo, ainda não descreveria o agente causador da lepra. Ainda lhe faltavam algumas peças desse quebra-cabeças científico. Sabedor dessas limitações, preferiu abusar de recursos argumentativos condicionais, no intuito de - assim interpreto - fixar sua prioridade acadêmica no processo:

Se conseguir comprovar com o tempo a suposição anteriormente mencionada sobre a natureza dos elementos marrons, então estará completamente provada a especificidade bacteriológica desse elemento. E, desse modo, chegaremos a conhecer as condições de vida desse bacilo, bem como suas condições de transmissibilidade para poder afirmar com toda segurança que se trata do agente causador da lepra. Esse vai continuar sendo, como sempre foi, o objetivo de meu trabalho (Hansen, 1880, p.41-42). ${ }^{27}$

Hansen tampouco pôde demonstrar, detalhadamente, o processo de transmissão da doença entre seres humanos, questão ainda sujeita a muitas incertezas nos dias atuais (Yoshie, 1973; Irgens, 1973; Obregón-Torres, 2000; Monteiro, 1995; Maciel, 2007; Cabral, 2007). O que fez - e, é preciso dizer, também Neisser - foi constatar que o microrganismo observado, desde 1848, por Danielsen era, de fato, uma bactéria. Assim, por ser encontrada em todos os pacientes com lepra, muito provavelmente, deveria ser a causadora da doença.

Nos anos posteriores à referida publicação, saíram vários outros artigos de Hansen no Virchows Archiv (Hansen, 1882, 1883, 1886, 1888, 1890). A análise desses trabalhos revela outros elementos importantes que contribuíram para a consagração de Hansen como principal cientista nos estudos etiológicos sobre a lepra, tais como sua retórica antihereditariedade. O médico norueguês conseguiu firmar-se no cenário científico europeu antes pela força dos argumentos com que criticava a concepção hereditária da lepra do que propriamente por evidências que embasassem suas afirmações sobre a transmissibilidade, mesmo porque a mera descrição do bacilo ainda não bastava como prova de que seria o responsável por originar a doença em seres humanos. Ainda que sem a mesma força, partidários da hereditariedade da lepra continuaram a atuar no meio científico, mesmo após a descrição do agente etiológico por Hansen e Neisser. 
No artigo "Studien über Bacillus leprae", de 1882, Hansen descreve a continuidade de suas tentativas de inoculação da bactéria em animais, ainda sem sucesso. Apesar disso, são reiteradas as críticas à teoria hereditária: "Depois de eu ter mostrado, no passado, que a disseminação e o agora desaparecimento da lepra da Noruega estão vinculados à assunção da doença como contagiosa, é preciso abandonar para sempre o legado da hereditariedade dessa doença" (Hansen, 1882, p.545). ${ }^{28}$

Muito provavelmente em decorrência do reconhecimento acadêmico obtido com a descoberta do Bacillus leprae, Hansen assumiu, em 1883, o cargo de chefe do Serviço Nacional de Lepra da Noruega, em substituição a Danielsen (Hansen, Lie, 1909). Iniciou-se, então, uma fase mais dura no combate à doença no país, com ênfase no isolamento compulsório de todos os doentes em leprosários estatais, além de uma série de outras medidas coercitivas (Irgens, 1973; Bechler, 2010).

As críticas à postura de Hansen no meio político norueguês tornaram-se mais veementes, especialmente quanto à sua visão radical da hereditariedade. Em 1887, ele solicitou ao parlamento norueguês autorização para uma viagem aos Estados Unidos, com a intenção de provar que as condições de vida e salubridade das pessoas influenciavam a incidência da lepra (Hansen, 1976; Larsen, 1973,). Sua proposta era simples: examinaria várias famílias de noruegueses que haviam emigrado para os Estados Unidos nas últimas décadas. Se apresentassem sinais da doença, a tese da hereditariedade mostrar-se-ia procedente. Caso contrário, estaria comprovado que a lepra era transmissível, e que a transmissão era favorecida pelas condições sanitárias em que viviam as populações. Em sua autobiografia, lê-se: "Cerca de 200 leprosos noruegueses haviam imigrado da Noruega, e eu tinha convicção de que provas concretas poderiam ser encontradas nesse cenário no sentido de confirmar minhas expectativas científicas" (Hansen, 1976, p.132). ${ }^{29}$

Hansen não encontrou um caso sequer de lepra entre os imigrantes noruegueses e conseguiu, assim, que sua ideia fosse definitivamente aceita em seu país (Hansen, Lie, 1909; Irgens, 1992). Após essa investigação epidemiológica, seu prestígio e poder na Noruega cresceram imensamente (Obregón-Torres, 2000; Bechler, 2009). Além disso, Hansen viu-se numa situação política extremamente favorável em seu país, por ter 'vencido' uma disputa científica contra um cientista estrangeiro.

No artigo "Die Erblichkeit der Lepra", publicado ainda no Virchows Archiv, em 1888, Hansen registrou as impressões daquela viagem em que acompanhou as histórias de 160 imigrantes escandinavos que se instalaram em três estados norte-americanos: "Nenhum sequer se tornou leproso. ... existe, assim, apenas uma interpretação possível, qual seja, a de que a lepra definitivamente não pode ser hereditária" (Hansen, 1888, p.561). ${ }^{30}$

Em outro artigo chamado "Ist die Lepra eine im Aussterben begriffene Infektionskrankheit und ist sie erblich?" (A lepra é uma doença em desaparecimento e é hereditária?), Hansen abordou de maneira mais direta o tema, afirmando que qualquer outro pensamento científico sobre a doença que não levasse em conta sua transmissibilidade seria pura "perda de tempo" (Hansen, 1890, p.484). Fazendo mais uma vez menção à viagem aos Estados Unidos, dizia: "Os resultados de minhas observações na América encaixam-se perfeitamente em minhas convicções teóricas, e eu considero ser relativamente fácil comprovar que a lepra não é uma doença hereditária" (Hansen, 1890, p.484). ${ }^{31}$ 


\title{
O papel de Robert Koch
}

A participação do bacteriologista alemão Robert Koch no processo de desvelamento do agente da lepra merece atenção. Com base em seus estudos sobre processos de coloração e seu emprego nas observações microscópicas de bactérias, Koch conseguiu realizar investigações decisivas sobre diversas enfermidades como cólera, febre amarela, tuberculose, entre outras (Gradmann, 2005). No caso do agente da lepra, sua incursão também seria vital, fato reconhecido por Neisser no já referido artigo de 1879: “Considero fundamental neste momento poder expressar minha gratidão aos senhores professores Ferdinand Cohn e doutor Robert Koch, que acompanharam o desenvolvimento de minhas pesquisas passo a passo" (Neisser, 1879, p.203). ${ }^{32}$ Ao regressar de Bergen com os preparados cedidos por Hansen, Neisser contou com a ajuda de Koch, obtendo vantagem decisiva na disputa, já que teve a oportunidade de submeter aqueles preparados às inovadoras técnicas de coloração desenvolvidas por seu professor. Hansen, muito provavelmente, percebeu essa desvantagem. Tanto que escreveu uma carta a Koch, colocando-o a par de seus estudos e solicitando sua ajuda (Hansen, 1880). Encontrei duas menções sobre a referida carta, a primeira, no já abordado artigo "Bacillus leprae", de 1880 (p.41):

\begin{abstract}
A explicação para o fato de os preparados não apresentarem os resultados me foi dada posteriormente pelo doutor Robert Koch, a quem escrevi uma carta ... Doutor Koch me aconselhou então a prestar atenção na qualidade dos materiais de coloração que estava utilizando, ou mesmo para o fato de que eu talvez estivesse realizando esse processo sem a devida energia. Esse erro, como me relatou o doutor Koch, também foi cometido pelo doutor Neisser, que somente após ter recebido a mesma orientação conseguiu fazer com que os preparados atingissem a coloração desejada, muito provavelmente por contar com o auxílio do senhor doutor Robert Koch. ${ }^{33}$
\end{abstract}

No artigo escrito por Hansen e Lie em 1909 (p.335), para a segunda Conferência Internacional de Lepra, realizada na capital norueguesa, consta o seguinte:

Quando as técnicas de coloração de bactérias de Robert Koch se tornaram conhecidas, Hansen tentou implantá-las em seus bastões. Os resultados foram, entretanto, insatisfatórios, até que ele recebeu a orientação de Koch de deixar os preparados descansando por mais tempo, por até 24 horas, para que apresentassem a coloração desejada, e ele realmente teve êxito. Foi quando Neisser, que esteve no laboratório de Hansen em Bergen, e com ele aprendeu os meandros da pesquisa sobre o assunto, publicou seus resultados. ${ }^{34}$

O reconhecimento tanto de Neisser quanto de Hansen da participação de Koch na 'descoberta' do agente da lepra não deixa dúvidas quanto à relevância de seus conhecimentos e metodologias na instauração desse paradigma. Além disso, as similaridades dos microrganismos da lepra e da tuberculose - este descoberto pouco depois (1882) por Koch - intrigava, à época, tanto esse como outros bacteriologistas. Posteriormente, estudos mais apurados levaram à classificação de ambos os bacilos no gênero Mycobacterium, em um processo que, àquela altura, já ganhava visibilidade internacional.

Torna-se aqui interessante ressaltar a participação de um cientista brasileiro nesse debate. Adolpho Lutz (1855-1940) dedicou-se ao estudo de inúmeras enfermidades tropicais. Nascido 
no Brasil, mas filho de pais suíços, Lutz construiu importantes redes acadêmicas internacionais, graças à sua formação acadêmica, realizada em vários países. Seus trabalhos versam sobre uma gama impressionante de assuntos, tendo contribuído decisivamente para o desenvolvimento de conhecimentos técnicos em temas como entomologia, parasitologia e bacteriologia, por exemplo. Nesses estudos, a lepra sempre teve valioso destaque. Lutz morreu acreditando que a doença era transmitida por mosquitos, crença que não se comprovou empiricamente. Ainda assim, foi substancial sua contribuição para a controvérsia científica sobre a lepra no século XIX, aqui narrada. Lutz ajudou, por exemplo, a desenvolver técnicas de coloração de células para os estudos dos materiais leprosos, em conjunto com o renomado dermatologista alemão Paul Gerson Unna. Além disso, o cientista brasileiro ainda proporia outra classificação para o microrganismo causador da lepra, associando-o ao da tuberculose (Benchimol, Sá, 2005, p.79). ${ }^{35}$

Ainda outro indício interessante da importância da disputa sobre o agente da lepra nos estudos posteriores de Koch sobre a tuberculose foi apontado pelo historiador alemão Hans Schadewaldt. Em instigante artigo sobre o desenvolvimento dos conhecimentos científicos a respeito da lepra no século XIX, o autor faz menção a uma correspondência de Robert Koch a seu amigo e também bacteriologista Wilhelm Roser, em 12 de março de 1880. Na carta, Koch narra o recebimento de material leproso enviado diretamente por Armauer Hansen, deixando claro que o contato entre os dois cientistas não se restringiu ao pedido de auxílio solicitado pelo norueguês, ainda no final de 1879, conforme já mencionado:

\begin{abstract}
Nas últimas semanas, recebi um material bacteriológico extremamente interessante, e não poderia perder a oportunidade de enviar ao senhor dois preparados prontos. Tratase da lepra, cuja pesquisa técnica vem sendo desenvolvida nos últimos anos por Armaur Hansen (sic!) em Bergen, que já havia encontrado organismos que chamou de bastões, mas que agora os chama de bacilos, e assim os quer descrever. Hansen me enviou alguns fragmentos de pele... um deles ficou tão colorido que o núcleo ficou azul e o bacilo, vermelho. É necessário um bom microscópio para visualização. O segundo, eu colori tanto que o bacilo ficou azul, e o tecido da pele marrom... Isso é um impressionante exemplo de como objetos até agora invisíveis podem ser reconhecidos como um choque através da utilização de corretos materiais de coloração, ou vamos dizer melhor, de corretas reações químicas. Eu estou bastante interessado nesse material (Koch, 1880 citado em Schadewaldt, 1982, p.196). ${ }^{36}$
\end{abstract}

Como aponta Hans Schadewaldt (p.137), Koch utilizaria a mesma técnica de coloração um ano mais tarde em suas pesquisas sobre a tuberculose e, desse modo, essa outra descoberta está de algum modo relacionada ao contato científico entre Koch e Hansen. ${ }^{37}$

\title{
O fator Rudolf Virchow
}

A decisão de Albert Neisser de publicar seu artigo de 1879 - que considerava tão "revolucionário" - em uma revista científica de pequeno porte, e ainda em sua primeira edição, é prova de sua falta de experiência e legitimidade científica (Bourdieu, 1975).

Porém, outros fatores pessoais e acadêmicos merecem ser reconhecidos nesse processo. Como ressaltei já, a principal revista médica europeia do período era Archiv für patologische Anatomie und Physiologie und für klinische Medicin, também conhecida como Virchows Archiv. 
Não encontrei indícios de uma possível tentativa de Neisser em nela publicar seu artigo, muito menos de uma eventual recusa de Virchow em fazê-lo. Ainda assim, considero plausível que tal tentativa tenha sido feita. Afinal, Neisser sabia que não poderia haver outro instrumento de divulgação mais adequado para uma publicação julgada tão "revolucionária". Além disso, como conterrâneo de Virchow, Neisser poderia ter tirado proveito do sentimento nacionalista bastante em voga, na ocasião, para conquistar a oportunidade da publicação que, seguramente, mudaria a sua vida.

Virchow, por sua vez, em vários momentos, externou sua predileção acadêmica e pessoal pelos pesquisadores noruegueses, especialmente por Armauer Hansen. Sua viagem a Bergen, no final da década de 1850, já referida, foi decisiva para o estreitamento dessas relações. Quando Hansen iniciou o processo de divulgação de seus resultados, encontrou em Virchow um importante aliado. Em vários momentos, a relação respeitosa entre ambos ficou evidente. Por exemplo, na primeira Conferência Internacional da Lepra de Berlim, realizada em 1897, Virchow se referiria a Hansen como "meu amigo pessoal" (Mittheilungen..., 1897, p.32).

É relativamente bem explorado pela historiografia - especialmente a alemã - o tema das difíceis relações entre Virchow e Koch ao longo de anos de discussões acaloradas e de artigos antipáticos de parte a parte. ${ }^{38}$ Georg Gruber narra acontecimentos emblemáticos dessa conturbada relação, deixando claro que os dois cientistas nunca falaram a mesma língua e que faziam de tudo para desvalorizar as conquistas científicas propagadas pelo outro (Gruber, 1939).

Assim, como assistente de Koch, Neisser estava em flagrante desvantagem em relação a Hansen, no que diz respeito ao editor da principal revista científica europeia do período, Rudolf Virchow, devido a essa condição de personagem fundamental na arregimentação de forças necessárias para consolidar a 'descoberta' do agente causador da lepra. Indiscutivelmente, Hansen pôde ostentar mais 'autoridade científica' do que Neisser para assumir o papel de 'descobridor'. Era mais experiente, mais bem relacionado academicamente que seu concorrente e publicara seu trabalho nas então principais revistas científicas do mundo.

Pode-se argumentar que o alemão Albert Neisser foi, na verdade, o primeiro cientista a descrever o agente da lepra, de acordo com as técnicas cientificamente mais avançadas para a época. Ele publicou os resultados de sua pesquisa antes de Armauer Hansen, graças ao já referido auxílio de Robert Koch. Esses fatos, entretanto, não foram suficientes para lhe assegurar o devido reconhecimento. Somente em 1881, Neisser teria a oportunidade de publicar um artigo no Virchows Archiv. Nessa oportunidade, deixou claro que abdicava dos louros de tal descoberta, em uma atitude singular e interessante:

\begin{abstract}
Gostaria ainda de fazer uma observação no que diz respeito às publicações de Hansen e Danielsen. Esclareço a esses autores com estas palavras, que nunca pretendi destacar minha prioridade nos estudos sobre a etiologia da lepra, principalmente em minha publicação no Breslauer Zeitschrift de 1879. Abro mão do mérito de ter realizado a descrição até então não feita do microrganismo causador da lepra, porque fui apenas coincidentemente o primeiro a conseguir fazer uma detalhada investigação a esse respeito, utilizando o método da coloração de Robert Koch (Neisser, 1881, p.541). ${ }^{39}$
\end{abstract}

O processo de legitimação do 'novo paradigma', contudo, não foi muito rápido nem tranquilo. Como mencionado, Hansen tampouco apresentou uma argumentação 
contundente, capaz de dirimir todas as dúvidas sobre o assunto e legitimar em definitivo a tese da transmissibilidade. De todas as maneiras, delineava-se um panorama histórico desfavorável a Neisser, no qual permaneceria até os dias atuais a imagem de cientista oportunista, à margem do processo de produção do agente etiológico da lepra.

\section{Considerações finais}

Nas duas primeiras décadas do século XX, observa-se um profícuo processo político e acadêmico de solidificação do paradigma etiológico da lepra. A efervescência de sentimentos nacionalistas se faria sentir na produção científica do período. No caso específico da Alemanha, esse nacionalismo manifestou-se de forma mais veemente em relação à França, desde a vitória germânica na Guerra Franco-prussiana. Emblemático dessa questão é o fato já bem enfatizado pela historiografia europeia - por John Cornwell, por exemplo - da renúncia de Louis Pasteur ao Diploma Honorário da Universidade de Bonn. O decano do corpo docente respondeu na ocasião que, em vista do "insulto que o senhor ousou fazer à nação alemã, na sagrada pessoa de nosso augusto imperador, a carta, com sua manifestação de total desprezo, estava sendo devolvida, para proteger nossos arquivos contra a poluição" (citado em Cornwell, 2003, p.61).

Nessa atmosfera, ciência e política amalgamavam-se com tênues linhas demarcatórias, quase nunca bem delimitadas. Toda produção científica universalmente reconhecida passava a ser importante predicado das nações europeias no período. No caso da lepra, doença tão relevante do ponto de vista político e científico, a produção do descobridor de seu agente etiológico tornava-se, indubitavelmente, um feito venerável.

Albert Neisser faleceu em 1917, às vésperas da eclosão da Primeira Guerra Mundial. O médico alemão Albert Czaplewski escreveu então um trabalho fundamental sobre a participação de Neisser na querela acerca da descoberta do agente da lepra. Defendendo-o com veemência, reivindicava mais respeito e reconhecimento acadêmicos para seu conterrâneo. Segundo Czaplewski (1917), a falta de reconhecimento e o desrespeito tinham feito de Neisser uma pessoa amarga e triste até o fim de sua vida, e por esta razão, esforçavase o autor em devolver ao médico de Breslau o lugar que merecia no cenário científico mundial.

A empresa, contudo, não rendeu os resultados esperados, e Hansen foi consagrado como único 'descobridor' da bactéria da lepra.

A partir da inquietação resultante da observação das condições de vida dos conterrâneos no interior do país, e impulsionado pelas ideias de Darwin, o médico norueguês efetivamente conseguiu derrubar barreiras, conceitos e paradigmas, transformando-se no principal ícone científico da lepra, tendo seu nome para sempre a ela associado.

Se, a partir de então, a lepra passou a ser doença com princípios científicos, vários enigmas permaneciam intactos como, por exemplo, a maneira pela qual se dava sua transmissão. Considerando que a grande era da bacteriologia na ciência médica tenha acontecido em meados da década de 1880, com as descobertas dos agentes etiológicos de várias doenças, como a tuberculose, o cólera, o tétano e outras, a datação da 'descoberta' do agente etiológico da lepra em 1879-1880 exerce um papel fundamental no estudo desse ramo da medicina 
no final do século XIX - especialmente se levarmos em conta a atitude de Hansen de, já em 1874, publicar um artigo supondo ser a lepra transmissível apenas em função dos "elementos marrons" que havia observado.

Hansen tomou essa atitude, conforme apontam alguns autores, antes mesmo da consolidação das importantes teorias e paradigmas impostos por Robert Koch e Louis Pasteur (Yoshie, 1973; Blom, 1973). A 'descoberta' - que aqui considero ter sido de Hansen e Neisser - assume assim um importante papel científico no final do século XIX, abrindo novas perspectivas para o estudo de enfermidades que tanto assustavam a sociedade da época.

A interpretação histórica que faço da presente querela científica passa indubitavelmente por uma análise da produção científica sobre o assunto até o presente momento. Para a realização desse intento, se faz imperioso constatar o fato de que Hansen, como já afirmei, saiu vencedor da disputa. Assim, seu espaço na ciência da época foi naturalmente muito maior do que o de Neisser. Para tanto, foi fundamental a conferência de Berlim de 1897. Realizada 18 anos após o início da disputa com Neisser, ou seja, da visita do alemão a Bergen, foi exatamente na capital alemã que Hansen experimentou a importância pessoal dessa 'descoberta': "Claro que eu tive fama com isso. E isso aconteceu, aparentemente em 1897, na conferência de lepra de Berlim" (Hansen, 1976, p.101). ${ }^{40}$

Nos anos subsequentes, a querela mostrou-se resolvida cientificamente. Com exceção do trabalho citado do também alemão Czaplewski, publicado em 1917, que tentou dar a Neisser um pouco mais de visibilidade e mesmo de respeito, torna-se patente que a comunidade científica aceitou a supremacia de Hansen até a década de 1950. A partir da década de 1960 - e, principalmente, a partir da publicação International Journal of Leprosy and mycobacterial diseases - houve uma tentativa de reinterpretação do processo, observável até meados da década de 1970. Fite e Wade escreveram, em 1955, o primeiro trabalho que deu nova luz ao problema, no qual Neisser é retratado senão como o 'descobridor' da bactéria, pelo menos com um pouco mais de respeito, e como parte realmente ativa no processo. A partir de então, foram publicados vários trabalhos na mesma revista - como os de Vogelsang, em 1963, Wade, em 1964, e Feldman, em 1965 -, tendo como principal objetivo revisitar o momento inicial do estudo científico da lepra. Cabe ressaltar que todos os autores eram noruegueses, e seus discursos transmitem pesado teor nacionalista, tencionando defender o papel preponderante e hegemônico de Hansen no processo.

Em 1973, surgiu uma nova série de trabalhos sobre o tema na referida revista. Apenas nesse ano, foram publicados os trabalhos dos também noruegueses Blom, Larsen, Irgens, como também do brasileiro Bechelli e do japonês Yoshie. A perspectiva dominante nesses últimos trabalhos foi a de que Hansen havia alcançado de tal forma o status de paradigma, que sua imagem estaria para sempre associada à história da lepra, independente de qualquer disputa científica.

Na mesma linha de pensamento, em 1992, o norueguês Irgens publicou um trabalho sobre a relevância do aniversário de 150 anos do nascimento de Hansen, no qual fica ainda mais clara essa concepção do cientista norueguês como um ícone quase inatingível na história da lepra em todos os tempos.

Em 2000, a historiadora colombiana Obregón-Torres publicou, em sua tese de doutorado, a primeira obra latino-americana que tentou trazer a questão da etiologia da lepra 
novamente à tona. Já dotada de um arcabouço teórico relativista e culturalista, muito embora pautando-se quase exclusivamente em fontes secundárias, a autora entende a 'descoberta' como um processo, no qual as figuras de Hansen e Neisser apareceram em conjunto. Tal perspectiva ressoaria em trabalhos posteriores no continente, especialmente no Brasil, como nos de Laurinda Rosa Maciel, Dilma Cabral e na obra conjunta de Jaime Benchimol e Magali Romero Sá, constituindo, assim, em última instância, a linha teórico-metodológica com a qual este trabalho mais se alinha, de todas as citadas. Nesse sentido, o artigo ora apresentado pretende contribuir para as discussões sobre a temática na América Latina, posto que apresenta diversas fontes primárias que versam sobre o processo de formação desse paradigma e que ainda permaneciam inéditas no continente.

O agente etiológico da lepra foi descrito, portanto, por Hansen e Neisser, num conturbado processo, que exteriorizou diversos elementos políticos, nacionais, culturais e científicos. Ao fim e a cabo, o norueguês Armauer Hansen é considerado atualmente o 'descobridor' do posteriormente denominado Mycobacterium leprae. O estudo da lepra, sem dúvida nenhuma, deve muito a esse cidadão de Bergen. Sua obstinação científica conseguiu fomentar a produção de conhecimentos técnicos sobre uma enfermidade bastante singular, em um período histórico dos mais turbulentos. Problematizar essa produção significa reconhecer, antes de tudo, o caráter vanguardista dessas tentativas e a proficuidade do ambiente no qual ela foi desenvolvida. Da mesma forma, significa valorizar aspectos humanos dos personagens que a produziram, buscando aproximar o ângulo de observação histórica do momento de sua concepção. Nesse sentido, a explanação do próprio Hansen (1976, p.132) sobre sua 'descoberta' torna-se reveladora:

Isso me deixou bastante desconfortável, pois eu não posso considerar minha descoberta um trabalho de magnitude. Foi algo que, inevitavelmente, aconteceria com o tempo. Qualquer pessoa com inteligência, amor pelo trabalho e talento teria revelado, se conseguisse dedicar tempo suficiente de sua vida a esse estudo. Acontece que eu tinha um intenso interesse pelo que estava pesquisando, era jovem e tinha sido criado com entusiasmo para o trabalho intenso. Eu estou inclinado a acreditar que isso vale para todas as áreas científicas: trabalho árduo, e uma boa reflexão serão sempre os meios de se chegar a algo de valor. $^{41}$

\footnotetext{
NOTAS

1 "Er ist der Mann, der wohl der eigentlich Vater der Maßregeln war, die in den folgenden Jahren gegen die Lepra getroffen wurden". Nesta e nas demais citações de texto em língua estrangeira, a tradução é livre.

${ }^{2}$ Atual Oslo.

3 “teils die Leprösen zu heilen, teils den armen Aussätzigen eine gute Verpflegung zu geben und soviel wie möglich von der Vermehrung der Bevölkerung fernzuhalten".

4 "Ich gehe morgen früh nach Lübeck fort, um von da nach Bergen zu gehen. Der Hauptdistrict aber, in welchem die Krankheit herrscht, derentwegen die norwegische Regierung meine Ansicht über den Stand der Lepraforschung zu hören wünscht, ist Bergen-Stift. Dort werde ich mich also wohl am längsten aufhalten. Ich soll dort 5 bis 6 Wochen bleiben und hoffe, dass ich was dafür tun kann".

5 "mere clumps of degenerated fat". Contudo, é interessante constatar que, em estudos posteriores, Virchow alteraria sua visão inicial sobre essas massas granulares, classificando-as como "células leprosas". A esse respeito, ver Feldman, 1965.
} 
${ }^{6}$ Dois anos mais tarde, Hansen casou-se novamente. Com sua segunda esposa teve um filho de nome Daniel Cornelius Armauer Hansen, que anos mais tarde também se tornaria leprologista.

7 "A very religious person".

8 "I suffered terribly. I had never seen so much misery concentrated in one place".

9 "Naturally it was no longer possible to fully concentrate on one's work. Even I, a foreigner, found it difficult to sit quietly at my microscope under the circumstances".

10 "It was in Vienna, too, where one of the most important occurrences in my life happened. It began in ordinary enough fashion with my walking into a bookstore but when I came upon a copy of "Natural Evolution" fate was at my elbow. The title itself challenged everything I had been taught about creation. I went home fascinated by my purchase and for two days read it to the complete neglect of my laboratory. Never had I read anything like it. The whole world stood out in an entirely different light than that which I had know. All I had been taught as a child collapsed as something unreal".

11 "My scientific searching had prepared me to spiritually absorb the mental schock of those two days".

12 "Let me first discuss yet another point which belongs here. It is this: people in their craving for the answer to the riddle of life - yet understanding it so little - imagine they have reached a solution by creating a God from whom everything springs and who is truly the Almighty. They ignore that this God also demands an origin. Avoinding this demand by merely making him omnipotent and eternal is simply an admission of ignorance".

13 "Since the results of the examinations are still uncertain and I intend to continue the research, I did not want at this time to mention in reports the details of my records. Many things are still lacking for the direct demonstration of specificity for leprosy, but I also thought I should give in this report an account of my examinations, which I had intended to do".

14 "Er studierte zuerst die klinischen Phänomene und die pathologische Anatomie der Krankheit. Die so genannten Virchowschen Leprazellen, die schon vor vielen Jahren von Danielsen in seiner Arbeit über die anästhetische Form des Aussatzes beschrieben waren und die er für etwas der Lepra Eigentümliches ansah. Hansen nannte sie 'braune Körper' und fand sie überall in den leprösen Produktionen, erkannte auch, daß sie nicht als degenerierte Zellen, wie Virschow zu Begin interpretierte, angesehen werden konnten und meinte, sie wären für die Lepra charakteristische Bildungen. ... Durch diese Beobachtung und durch die, daß die Leber, die Milz und die Testikeln bei den knotigen Patienten immer leprös affiziert waren, und durch die klinischen Beobachtungen des Verlaufes der Krankheit erlangte er die Überzeugung, daß die Lepra eine spezifische Krankheit wäre, daß sie auch eine spezifische Ursache haben mußte, und daß Danielsen-Boecksche Lehre von ihrer Ätiologie kaum richtig sein konnte" (grifo do autor).

15 "While leprosy may be thus indirectly proved to be a specific disease by demonstrating its contagiousness, it would, of course, be the best if a direct proof could be given. I will briefly mention what seems to indicate the such proof is, perhaps, attainable. There are to be found in every leprous tubercle extirpated from a living individual - and I have examined a great number of them - small staff-like bodies, much resembling bacteria, lying within the cells. ... It is worthy of notice, however, that the large brown elements found in all leprous proliferations in advanced stages... bear a striking likeness to bacteria in certain states of development".

${ }^{16}$ Em linhas gerais, os postulados pretendiam constituir um parâmetro para o reconhecimento de uma bactéria. Para que o microrganismo fosse reconhecido como tal, deveria atender a três requisitos básicos, quais sejam: o bacilo deveria estar presente em toda a amostra colhida em pacientes; deveria ser cultivado fora do organismo humano, ou seja in vitro; e o bacilo cultivado deveria ser capaz de induzir a doença por inoculação em um ser humano ou animal. Para saber mais sobre o assunto, ver Gradmann, 2005.

${ }^{17} \mathrm{Na}$ obra Handbuch der systematischen Anatomie des Menschen, publicada ainda em 1855, Henle iniciou sua luta para compreender melhor os cada vez mais observáveis microrganismos como causadores de enfermidades. Posteriormente, desenvolveu conceitos como contagium vivum, ou contagium animatum, que contribuíram para os estudos realizados por diversos pesquisadores sobre doenças como a lepra. Para saber mais sobre o assunto, ver Dross, Salimi, 2009.

18 "Auf unserer letzten Station, in Bergen, waren wir noch in liberalster Weise mit Präparaten versehen worden, und dann wurde es mir klar, es wäre eine Frage der Zeit, dies in Kochsmethoden einfügen zu können. Als ich mit einigen Präparaten in die Heimath zurückkehrte, machte ich mich sofort an die Untersuchung des gesammten Materials und fand zu meiner grossen Überraschung, ja zu meinem Erstaunen überall, in sämmtlichen 14 Hautstücken und Knoten, in Leber, Milz, Hoden und Hornhaut, die gänzlich unbekannt waren, und dann habe ich den Mut, durch weiteres Nachforschen zur Aufhellung des so dunklen Krankheitsgebietes beitragen zu können". 
${ }^{19}$ Tais técnicas foram desenvolvidas para estudos histológicos, sendo logo absorvidas e aperfeiçoadas no âmbito da bacteriologia. Hermann Hoffmann (1819-1891) foi o primeiro a recorrer à coloração de bactérias no final dos anos 1850; em 1877, C. Salomonsen (1847-1924) conseguiu corá-las utilizando uma solução aquosa de fucsina. Koch contribuiu para o processo quando, no final da década de 1870, diferenciou métodos de coloração conforme o pH ácido, básico ou neutro da substância empregada. Além disso, "para imobilizar as bactérias, Koch desenvolveu um engenhoso processo de secagem que não interferia em sua forma primitiva" (Benchimol, Sá, 2005, p.60). Alguns anos mais tarde (1884), o dinamarquês Christian Gram desenvolveria o método universalmente reconhecido, que consiste basicamente no uso da fucsina amoniacal e na divisão das bactérias em "gram-positivas" e "gramnegativas", conforme sua capacidade de fixar o corante.

20 "eine Revolution in der Ätiologie der Lepra".

21 "Die Bacillen sind kleine schlanke Stäbchen, deren Länge etwa die Häfte des Durchmessers eines rothen menschlichen Bluttkörperchens beträgt und deren Breite ich auf $1 / 4$ der Länge schätze. ... In ungefärbten Schnitten vermochte ich diese winzigen Organismen nicht zu erkennen. Am schönten treten sie bei Fuchsin und Gentiana-violett-Färbungen hervor. Ihre Anordnung richtet sich nach dem Raum, in den hinein sie sich entwickeln".

22 "Wie resultatlos aber diese Discussionen alle geblieben sind, werden Sie am besten daraus ersehen, dass die beiden bedeutendsten Lepra-Kenner, die zur Zeit leben, die beide in entgegengesetzte wissenschaftliche Richtungen arbeiten... Danielsen und Hansen aus Bergen. Ich sage, dass diese beiden Forscher auf grade entgegengesetzten Standpunkten stehen. Danielsen betrachtet die Lepra als eine erbliche Krankheit und leugnet die Contagiosität, während Hansen die Krankheit für eine rein contagiöse erklärt und sich bemühlt, seine eigene Eitelkeit zu rühmen".

23 "I didn't think there was any particular hurry to publish my discovery since I felt there was still a great deal to be done before one could claim that the bacillus was definitely the origin of the disease. Not so Neisser. He published immediately, though honestly reporting what I had demonstrated for him. Unfortunately he also recorded a conversation whit Danielsen in which my chief had asked him, 'ironically' - according to Neisser - if I had show him my bacillus. Apart from this detail, I was inclined to take the move to anticipate me without excitement since I had already reported the actual discovery to the Norwegian Magazin of Medical Science".

24 "Danielsen was absolutely furious, though, especially over Neisser's description of his attitude towards my bacillus. He told me off severely for my indolent concern over the matter since, in his opinion, there was a definite and deliberate attempt to steal my finding".

25 "Als Schlußbemerkung möchte ich noch wiederholen, daß in derselben Richtung bereits frühere Autoren, am exaktesten unter ihnen Hansen, gearbeitet und sich ausgesprochen haben. Ich meinerseits habe ich mich bemühlt, eine ganz bestimmte Bakterienform und ihre Verbreitung im Organismus, dem Auge eines jeden zugänglich, nachzuweisen".

26 "Ich hatte noch nicht daran gedacht meine Untersuchungen über diesen Gegenstand zu publiciren, ... aber weil Dr. Neisser aus Breslau, der in diesem Sommer sich einige Zeit in Bergen aufhielt, um den Aussatz zu studieren, gerade die Resultate seiner Untersuchung an den Präparaten, die er von hier mitgebracht, veröffentlicht hat ... so finde ich mich veranlasst mitzutheilen, was ich darüber bisher erreicht habe. Es geschiebt dies, theils um meine Priorität in dieser Frage bei den akademischem Publikum zu sichern, theils um diesem letzteren die Detailuntersuchungen mitzutheilen, die ich wegen des noch so unsicheren Resultats zurückhielt, als ich der medicinischen Gesellschaft in Christiania 1874 einlieferte".

27 "Sollte nun die oben ausgesprochene Vermuthung von der wahren Natur der braunen Elemente mit der Zeit sich als Wahrheit bewähren, so würde die Specificität derselben Elemente vollständig bewiesen sein, und es würde dann weiter darauf ankommen, die Lebensbedingungen dieser Bacillen kennen zu lernen, und durch weitere Versuche ihre Uebertragbarkeit darzulegen, um endlich mit voller Zuverlässigkeit alle Zweifel an der eigentlichen Ursache des Aussatzes verschwinden zu lassen. Und dies soll wie früher das Ziel meiner Arbeit sein".

28 "Nachdem ich früher dargethan haba, dass die Ausbreitung und das jetzige Verschwinden der Lepra in Norwegen durch Annahme der Contagiosität am besten verständlich wird, muss man wohl die Lehre von der Erblichkeit dieser Krankheit für immer fallen lassen".

29 "Approximately 200 Norwegian lepers had immigrated there and I had the conviction that further concrete evidence towards the confirmation of my claim could be found in that setting". 
30 "ist kein einziger leprös geworden. Dies ist kurz gefasst, das Resultat meiner Forschungen, und es giebt wohl nur eine mögliche Deutung dafür, die nämlich, dass die Lepra definitiv nicht erblich sein kann".

31 "Das Resultat meiner Beobachtungen in Amerika steht somit in der erfreulichsten Übereinstimmung mit meinem theoretischen Schlüssen, und ich erachte es als ziemlich klar bewiesen, dass die Lepra keine erbliche Krankheit ist".

32 "und ich halte es für sehr werthvoll, dies bereits an dieser Stelle aussprechen zu dürfen - von Herren Prof. Ferd. Cohn und Dr. Koch, welcher letztere meine sämmtlichen Studien auf diesem Gebiete Schritt für Schritt begleitet hat".

33 "Als Grund dafür, dass die Präparate sonst nicht gelungen sind, muss ich nach einem Schreiben des Dr. Koch, an den ich mich um Rath gewandt habe, entweder die Eigenschaft des mir zu Gebote stehenden Farbstoffes oder den Umstand ansehen, dass ich zu wenig energisch gefärbt habe, welcher Fehler, wie Dr. Koch mir erzählt, auch von Dr. Neisser gemacht worden ist, so dass derselbe erst später glücklicher gewesen ist und bessere Präperate erhalten hat, was von der bewährten Erfahrung und Leitung des Hrn. Dr. Koch höchst wahrscheinliche abhängig gewesen ist".

34 "Als Kochs Färbungsmethoden für Bakterien bekannt wurden, versuchte Hansen dieselben auf seine Stäbchen. Die Färbung gelang aber nicht, bevor er von Robert Koch den Rat bekam, die Präparate längere Zeit, bis zu 24 Stunden zu färben, und er hatte gelungene Präparate, als Neisser, der in Bergen Hansens vergeblichen Versuchen der Färbung beigewohnt hatte, seine Resultate publizierte".

${ }^{35}$ Lutz propunha que os dois microrganismos fossem enquadrados na mesma família criada por ele: a dos Coccothricaceae. Anos mais tarde, suas pesquisas seriam suplantadas pelas de Karl Lehmann e R. Neumann, que incluíam os referidos microrganismos na classe dos Mycobacterium. Alguns autores, entretanto, ainda afirmam que Lutz teria fornecido evidências necessárias para que Coccothrix fosse o nome válido, nos dando mais um exemplo da efervescência científica que pairava sobre a lepra nas últimas décadas do século XIX. Para saber mais sobre o assunto, ver Benchimol, Sá, 2005.

36 "Ein höchst interessantes Bakterienobjekt habe ich in den letzten Wochen bekommen und kann es mir nicht versagen, Ihnen zwei daraus gefertigte Präparate zu senden. Es betrifft die Lepra, in deren Produkten schon vor einigen Jahren ARMAUR HANSEN (sic!) in Bergen stäbchenförmige Körper gefunden aber erst jetzt als Bacillen erkannt und als solche beschrieben hat... HANSEN hat mir einen Hautknoten... geschickt ... das eine ist so gefärbt, daß die Kerne blau, die Bacillen in roth erscheinen. Es bedarf zur Auflösung eines guten Zeiss'schen Mikroskops. Das zweite habe ich so gefärbt, daß die Bacillen blau, die Hautgewebe braun aussehen... Es gibt dies ein frappantes Beispiel dafür, wie bis dahin unsichtbare Objekte durch eine richtige Verwendung von Farbstoff oder sagen wir lieber von chemischen Reactionen mir einem Schlage so auffallend kenntlich gemacht werden können. Ich bin sehr an dieser Material interessiert".

37 "dass Koch in einem direkten wissenschaftlichen Gedankenaustausch mit Hansen stand".

${ }^{38}$ Um importante episódio entre os dois bacteriologistas, envolvendo diretamente a história da lepra, deu-se na já referida conferência internacional, realizada em Berlim, em 1897. Eleito pelo governo alemão presidente da conferência, Virchow veta pessoalmente a presença de Robert Koch ao encontro. Para saber mais sobre o assunto, ver Bechler, 2010.

39 "Ich möchte noch eine Bemerkung machen, was es um die Publicationen von Danielsen und Hansen betrifft. Ich kläre diesen Autoren hiermit, daß ich nie daran gedacht habe, meine Priorität bei den Studien über Ätiologie der Lepra hervorzuheben, besonders bei meiner Publlication in der Breslauer Zeitschrifft von 1879. Ich verzichte also auf den Vorzug, eine bis dahin noch nicht geschehende Beschreibung der Lepraerreger zu leisten, da ich nur zuffälig der ersten Wissenschaftler war, der eine detaillierte Untersuchung darüber ausübte, durch die Färbungsmethoden von Robert Koch".

40 "I have, of course, become famous through it. This was apparent in 1897 at the leprosy conference in Berlin".

41 "It made me rather uncomfortable, because I can't consider my discovery a work of magnitude. It was something that inevitably had to come with time, something anyone with intelligence, love of work and talent would have revealed when he had dedicated enough of his life to its study. It just so happened that I had an intense interest in what I was attempting, that I was young and that I had been created with a zest for hard labor. I'm inclined to believe that this in the criteria for all scientific accomplishment - hard work, sound thinking will always achieve something of worth". 


\section{REFERÊNCIAS}

ACKERKNECHT, Erwin.

Anticontagionism between 1821 and 1867 . Baltimore, v.22, p.562-593. 1948.

ALMAS, Reidar; BRYNJULV, Gjerdaker. Norwegian agricultural history. Trondheim: Tapir Academic. 2004

BECHELLI, Luiz M.

Advances in leprosy control in the last 100 years. International Journal of Leprosy and mycobacterial diseases, Bloomfield, v.41, n.3, p.285-297. 1973.

BECHLER, Reinaldo Guilherme. Leprabekämpfung und Zwangsisolierung im ausgehenden 19. und frühen 20. Jahrhundert: wissenschaftliche Diskussion und institutionelle Praxis. Doktorarbeit - Philosophische Fakultät I der Universität Würzburg. Würzburg. 2010.

BECHLER, Reinaldo Guilherme.

Muito mais do que isolamento em questão: ciência, poder e interesses em uma análise das duas primeiras Conferências Internacionais de Lepra - Berlim 1897 e Bergen 1909.

Temporalidades, Belo Horizonte, v.1, n.2, p.175-201. 2009.

BENCHIMOL, Jaime L.; SÁ, Magali Romero (Org.).

Adolpho Lutz, obra completa. v.1, livro 2:

Hanseníase. Rio de Janeiro: Fiocruz. 2005.

BLOM, Knut.

Armauer Hansen and human leprosy transmission - medical ethics and legal rights. International Journal of Leprosy and mycobacterial diseases, Bloomfield, v.41, n.2, p.199-207. 1973.

BOURDIEU, Pierre.

The specificity of the scientific field and the social conditions of the progress of reason. Social Science Information. s.l., v.14, n.6, p.19-47. 1975.

BRANNIGAN, Augustine.

The social basis of scientific discoveries.

Cambridge: Cambridge University Press. 1981.

CABRAL, Dilma.

Entre ideias e ações: lepra, medicina e políticas de saúde no Brasil (1897-1934). Tese

(Doutorado) - Departamento de História,

Universidade Federal Fluminense, Niterói. 2007.

CABRAL, Dilma.

A lepra e os novos referenciais da medicina brasileira no final do XIX. O laboratório bacteriológico do Hospital de Lázaros. In: Nascimento, Dilene; Carvalho, Diana;

Marques, Rita (Org.). - Uma história das doenças brasileiras. Rio de Janeiro: Mauad X. p.147-177. 2006.

CORNWELL, John.

Os cientistas de Hitler: ciência, guerra e o pacto com o demônio. Rio de Janeiro: Imago. 2003.

CUNNINGHAM, Andrew; WILLIAMS, Perry. The laboratory revolution in medicine. Cambridge: Cambridge University Press. 1992.

CZAPLEWSKI, Albert.

Albert Neisser und die Entdeckung der Leprabazillus. Archiv für Dermatologie und Syphilis, Wien, n.124, p.513-530. 1917.

DANIELSEN, Daniel C.; BOECK, Carl W. Traité de la spédalsked ou eléphantiasis de grecs. Paris: J.B. Ballière. 1848.

DROSS, Fritz; SALIMI, Kamran (Hrsg.). Jacob Henle: bürgerliches Leben und "rationalle Medizin". Fürth: Stadtarchivs und Stadtmuseums Fürth. Bd. 2. 2009.

EDMOND, Rod.

Leprosy and empire: a medical and cultural history. New York: Cambridge University Press. 2006.

FELDMAN, William $\mathrm{H}$.

Gerhard Armauer Hansen. What did he see and when? International Journal of Leprosy,

Washington, v.33, n.3, p.412-416. 1965

FITE, George L.; WADE, Hector M.

The contribuition of Neisser to the establishment of the Hansen bacillus as the etiologic agent of leprosy and the so-called Hansen-Neisser controversy. International Journal of Leprosy, Washington, v.23, n.4, p.418428. 1955.

FLECK, Ludwik.

Genesis and development of a scientific fact. Chicago: The University of Chicago Press.1979.

FOUCAULT, Michel.

O nascimento da clínica. Rio de Janeiro: Forense Universitária. 2006.

GRADMANN, Christoph.

Krankheit im Labor: Robert Koch und die medizinische Bakteriologie. Göttingen: Wallstein. 2005.

GRUBER, Georg B.

Robert Koch und Rudolf Virchow. Wien: Böhlau. 1939.

GUSSOW, Zachary.

Leprosy, racism and public health: social policy in chronic disease control. Boulder: Westview Press. 1989. 
HANSEN, Armauer.

The memories and reflections of Dr. G. Armauer Hansen. Würzburg: German Leprosy Rellief Association. 1976.

HANSEN, Armauer.

Ist die Lepra eine "im Aussterben begriffene" Infektionskrankheit und ist sie erblich?"

Virchows Archiv. Berlin, n.99, p.476-484. 1890.

HANSEN, Armauer.

Die Erblichkeit der Lepra. Virchows Archiv. Berlin, n.97, p.560-564. 1888.

HANSEN, Armauer.

Die Lage der Leprabacillen. Virchows Archiv. Berlin, n. 95, p.389-393. 1886.

HANSEN, Armauer.

Einige Bemerkungen über anästhetische Form des Aussatzes. Virchows Archiv. Berlin, n.91, p.557-565. 1883.

HANSEN, Armauer.

Studien über Bacillus Leprae. Virchows Archiv. Berlin, n.90, p.542-548. 1882.

HANSEN, Armauer.

Bacillus Leprae. Virchows Archiv. Berlin, n.87, p.23-45. 1880.

HANSEN, Armauer.

On the etiology of leprosy. British foreign medico-chirurgical review. London, v.55, p.459-489. 1875.

HANSEN, Armauer.

Undersogelser angaande Spedalskhedens Aarsager. Norsk Magazin for Laegevidenskaben. Bergen v.9, n.4, p.1-88. 1874. [Reprinted as "Causes of Leprosy". International Journal of Leprosy, Washington, v.23, n.3, p.307-310. 1955.]

HANSEN, Armauer.

Forelöbige Bidrag til Spedalskhedens

Karakteristik [Preliminary contribuitions to the characterization of leprosy] Nordiskt Medicinskt Arkiv Bergen, v.1, n.13, p.1-12. 1869.

HANSEN, Armauer; LIE, Hans Peter.

Die Geschichte der Lepra in Norwegen.

II Internationale Lepra-Konferenz, Bergen, v.2, p.314-340. 1909.

HOBSBAWN, Eric.

A era dos impérios. São Paulo: Paz e Terra. 1988.

IRGENS, Lorentz M.

Hansen: 150 years after his birth, the context of a medical discovery. International Journal of Leprosy and mycobacterial diseases, Bloomfield, v.60, n.3, p.466-479. 1992.

IRGENS, Lorentz M.

Leprosy in Norway: an interplay of research and public health work. International Journal of Leprosy and mycobacterial diseases, Bloomfield, v.41. n.2, p.189-198. 1973.

LARSEN, Oivind.

Gerhard Henrik Armauer Hansen seen through his own eyes: a review of his memories.

International Journal of Leprosy and mycobacterial diseases, Bloomfield, v.41, n.2, p.208-214. 1973.

LATOUR, Bruno.

Ciência em ação: como seguir cientistas $e$ engenheiros sociedade afora. São Paulo: Unesp. 1998.

LATOUR, Bruno; WOOLGAR, Steve.

A vida de laboratório: a construção dos fatos científicos. Rio de Janeiro: Relume-Dumará. 1997.

LÉONARD, Jacques.

Les médecins de l'Ouest au XIXème siècle. Paris: Champion. 1978.

MACIEL, Laurinda Rosa.

Em proveito dos sãos, perde o lázaro a liberdade: uma história das políticas públicas de combate à lepra no Brasil (1941-1962). Tese (Doutorado) - Departamento de História, Universidade Federal Fluminense, Niterói. 2007.

MITTHEILUNGEN...

Mittheilungen und Verhandlungen der internationalen wissenschaftlichen LepraConferenz zu Berlin im October 1897. Erste Sitzung. v.2. Berlin, p.3-45. 1897.

MONTEIRO, Yara.

Da maldição divina à exclusão social: um estudo da hanseníase em São Paulo. Tese (Doutorado) - Faculdade de Filosofia, Letras e Ciências Humanas, Universidade de São Paulo, São Paulo. 1995.

MORAES, Márcia Oliveira.

A ciência como rede de atores: ressonâncias filosóficas. História, Ciência, Saúde Manguinhos. Rio de Janeiro, v.8. n.1, p.321-333 2001.

NEISSER, Albert.

Weitere Bemerkungen zur Ätiologie der Lepra. Virchows Archiv. Berlin n.80, p.514-542. 1881.

NEISSER, Albert.

Bemerkungen zur Ätiologie der Lepra.

Schlesischen Gesellschaft für Vaterländische Kultur. Breslau, v.21, p.29-32. 1880.

NEISSER, Albert.

Zur Aetiologie der Lepra. Breslauer ärztliche Zeitschrifft. Breslau, n.1, p.201-203. 1879.

OBREGÓN-TORRES, Diana.

Batallas contra la lepra: Estado, medicina y ciência en Colômbia. Medellín: Fondo Editorial 
Universidad EAFIT. 2000.

RABL, Marie (Hrsg.).

Rudolf Virchow: Briefe an seine Eltern, 1839-1864. Leipzig: Schneider. 1906.

ROSENBERG, Charles.

Explaining epidemics and the other studies in the history of medicine. Cambridge: Cambridge University Press. 1992.

SCHADEWALDT, Hans.

Die wissenschaftliche Erforschung der Lepra in der Medizin des 18. bis frühen 20. Jahrhunderts. In: Henning, Jörn (Hrsg.). Aussatz, Lepra, Hansen-Krankheit: ein Menschheitsproblem im Wandel. München: Stelz-Druck München. p.193-198. 1982.

STERNERSEN, Oivind; LIBAEK, Ivar. The history of Norway: from the Ice Age to today. Lysaker: Dinamo Forlag. 2003.

STOLBERG, Michael.

Professionalisierung und Medikalisierung. In: Paul, Norbert; Schlich, Thomas (Org.). Medizingeschichte: Aufgaben, Probleme, Perspektiven. Frankfurt: Campus Verlag. p.69-86. 1998.

VASOLD, Manfred.

Rudolf Virchow und die Lepra in Norwegen. Medizinhistorisches Journal. Sttutgart, v.24, p.123-137. 1989.

VIRCHOW, Rudolf.

Zur Geschichte des Aussatzes, besonders in Deutschland, nebst einer Aufforderung an Aerzte und Geschichtsforscher. Virchows Archiv.
Berlin, n.25, p.45-71. 1864

VIRCHOW, Rudolf

Zur Geschichte des Aussatzes, besonders in Deutschland, nebst einer Aufforderung an Aerzte und Geschichtsforscher. Virchows Archiv, Berlin, n.22, p.234-256. 1862.

VIRCHOW, Rudolf.

Zur Geschichte des Aussatzes, besonders in Deutschland, nebst einer Aufforderung an Aerzte und Geschichtsforscher. Virchows Archiv, Berlin, n.20, p.459-512. 1861.

VIRCHOW, Rudolf.

Zur Geschichte des Aussatzes, besonders in Deutschland, nebst einer Aufforderung an Aerzte und Geschichtsforscher. Virchows Archiv, Berlin, n.18, p.138-162. 1860.

VOGELSANG, Thomas.

The Hansen-Neisser controversy 1879-1880. International Journal of Leprosy, Washington, v.31, n.2, p.74-80. 1963.

VOGELSANG, Thomas.

The Termination of Leprosy in Norway: An Important Chapter in Norwegian Medical History; Together with a Portrait of Armauer Hansen circa 1873. International Journal of Leprosy, Washington, v.25, n.4, p.345-51. 1957.

YOSHIE, Yoshio.

Advances in the microbiology of M. Leprae in the past century. International Jounal of Leprosy, Washington, v.41, n.3, p.361-371. 1973.

WADE, Hans.

First observation of the leprosy bacillus. International Journal of Leprosy, Washington, v.32, n.1, p.325-329. 1964.

\section{$\rightarrow \rightarrow \rightarrow<<<$}

